\title{
Biased $\mathrm{J}_{\mathrm{H}}$ usage in plasma cell immunoglobulin gene sequences from colonic mucosa in ulcerative colitis but not in Crohn's disease
}

\author{
D K Dunn-Walters, L Boursier, M Hackett, J Spencer
}

\begin{abstract}
Background-Ulcerative colitis is an inflammatory disease of the colonic and rectal mucosa. Autoantibodies have been observed in ulcerative colitis which may have a role in the pathogenesis of the disease. Evidence also suggests that there is an hereditary predisposition towards the disease, although no individual genes have been identified.

Aims-This is a pilot study of immunoglobulin heavy chain genes (IgH) in ulcerative colitis to determine whether they have any particular genetic characteristics which may lead to a better understanding of the disease aetiology.

Subjects-Colonic or rectal tissue was obtained from five children with ulcerative colitis. Tissue was also obtained from five children with Crohn's disease and five children who did not have inflammatory bowel disease as controls.

Methods-B cells and IgD+ B cells were identified by immunohistochemistry on frozen sections. Areas of lamina propria containing plasma cells, and areas of IgD+ B cells were microdissected. The immunoglobulin genes were PCR amplified, cloned, and sequenced. Sequences were analysed for content of somatic mutations and composition of heavy chain.

Results-An increase in the use of $\mathrm{J}_{\mathrm{H}} 6$ and DXP'1, and a decrease in the use of $J_{H} 4$, gene segments in immunoglobulin genes from lamina propria plasma cells, and from virgin IgD+ $B$ cells, was found in patients with ulcerative colitis. These biases were not present in the control groups. Conclusions-There is a fundamental difference in the immunoglobulin genes from patients with ulcerative colitis. Whether this is caused by a difference in content of immunoglobulin gene segments in the germline or a difference in the recombination mechanism is not known.

(Gut 1999;44:382-386)
\end{abstract}

UMDS St Thomas'

Campus, Department of Histopathology,

Lambeth Palace Road,

London SE1 7EH, UK

D K Dunn-Walters

L Boursier

M Hackett

J Spencer

Correspondence to:

Dr J Spencer.

Accepted for publication 7 October 1998 esis of this disease are unknown, there is substantial evidence to suggest that it is immunologically mediated. The humoral immune system has been implicated, possibly in response to autoantigen. There is a large relative
Keywords: ulcerative colitis; immunoglobulin heavy chain gene; joining region; diversity region; repertoire;

Ulcerative colitis is a chronic relapsing inflammatory disease of the colonic and rectal mucosa. Although the aetiology and pathogen- increase in the number of IgG-secreting cells, especially of the IgG1 subclass, and the ratio of IgA1 to IgA2 increases. ${ }^{1}$ Characteristic perinuclear anti-neutrophil cytoplasmic antibodies and antibodies against cytoskeletal proteins have been found. ${ }^{2-4}$ In addition, antibodies against a $40 \mathrm{kDa}$ epithelial antigen which co-localise with sites of complement deposition, and lymphocyte mediated cytotoxicity against epithelial cells have been reported. ${ }^{56}$ An association between ulcerative colitis and autoimmune diseases such as systemic lupus erythematosus, thyroid disease, and diabetes mellitus provides further evidence for the possible autoimmune aetiology.

Evidence suggests that there is an hereditary predisposition towards ulcerative colitis. It has been reported that the incidence of the disease is about 10 times greater when there is a positive family history. ${ }^{8}$ Studies of monozygotic twins and the association between some diseases with a clear genetic basis (sickle cell disease and Turner's syndrome) also support the idea that there is a genetic basis for the disease. ${ }^{9-11}$ Although linkage analyses have identified a number of loci that predispose to inflammatory bowel disease (IBD), no individual genes have yet been identified. ${ }^{12}$

A study of immunoglobulin genes can provide useful information which may help to determine the aetiology of disease. Whether or not an immunoglobulin gene is mutated, the extent of mutation, whether there are any specific mutations, and whether there are any biases in the gene segments used in rearrangement are all potential indicators of whether antigen is a contributory factor. Such studies have shown that B cells and plasma cells from normal intestinal mucosa differ from systemic B cells and peripheral blood lymphocytes (PBLs), in that they carry a much higher proportion of mutations in their $\operatorname{IgV}_{\mathrm{H}}$ genes. ${ }^{13}$ In this pilot study we have used immunohistochemistry, microdissection, and polymerase chain reaction (PCR) to isolate and sequence non-polymorphic $\operatorname{IgV}_{\mathrm{H}}$ genes from lamina propria (LP) plasma cells and IgD + B cells of children with ulcerative colitis. The sequences of these genes were analysed with respect to the number of mutations they carried in the $\mathrm{V}_{\mathrm{H}}$ region and the composition of the CDR3 regions of the gene where the junction between $\mathrm{V}_{\mathrm{H}}, \mathrm{D}$ and $\mathrm{J}_{\mathrm{H}}$ is located. $\mathrm{IgV}_{\mathrm{H}}$ gene sequences from colonic LP plasma cells in children with

Abbreviations used in this paper: IBD, inflammatory bowel disease; PBL, peripheral blood leucocyte; LP, lamina propria; PCR, polymerase chain reaction; SCID, severe combined immunodeficiency. 
Table 1 Tissue from which $\mathrm{IgH}$ genes were isolated

\begin{tabular}{llll}
\hline Patient & $\begin{array}{l}\text { Age } \\
\text { (years) }\end{array}$ & Tissue & Diagnosis \\
\hline UC1 & 15.3 & Colon & Ulcerative colitis \\
UC2 & 10.9 & Rectum & Ulcerative colitis \\
UC3 & 2.9 & Colon & Ulcerative colitis \\
UC4 & 11.1 & Colon & Ulcerative colitis \\
UC5 & 16.5 & Colon & Ulcerative colitis \\
C1 & 12.8 & Colon & Crohn's disease \\
C2 & 13.8 & Colon & Crohn's disease \\
C3 & 15.1 & Colon & Crohn's disease \\
C4 & 14.6 & Colon & Crohn's disease \\
C5 & 13.8 & Colon & Crohn's disease \\
N1 & 10.0 & Rectum & Non-IBD \\
N2 & 12.8 & Colon & Non-IBD \\
N3 & 12.9 & Colon & Non-IBD \\
N4 & 14.5 & Colon & Non-IBD \\
N5 & 14.7 & Colon & Non-IBD \\
\hline
\end{tabular}

IBD, inflammatory bowel disease.

Crohn's disease and from non-IBD colonic biopsy specimens were analysed as controls.

\section{Materials and methods}

TISSUE

Resected specimens of colon from patients with ulcerative colitis or Crohn's disease were snap frozen in liquid nitrogen within an hour of surgery and kept at $-70^{\circ} \mathrm{C}$. Non-IBD colonic biopsy samples were obtained from investigative colonoscopy where no evidence of ulcerative colitis or Crohn's disease was found. Table 1 shows the tissues used and the ages of the patients from which they were taken.

IMMUNOHISTOCHEMISTRY AND MICRODISSECTION All primary and secondary antibodies in this study were purchased from Dako Ltd, High Wycombe, Buckinghamshire, UK. Frozen sections $(7 \mu \mathrm{m})$ were cut on to poly-L-lysine coated slides and kept at $-20^{\circ} \mathrm{C}$ until required. Serial sections were immunostained with monoclonal antibodies to $\operatorname{IgD}$ (to identify surface $\operatorname{IgD}+$ naive B cells), UCHT1 (anti-CD3; to identify T cells), or L26 (anti-CD20; to identify mature B cells) as previously described. ${ }^{14}$ Sections for microdissection were left, without mountant or coverslips, to dry overnight.

Sections to be used for microdissection were stained with CD20. Microdissection of areas of LP that did not contain any CD20 cells or areas of IgD+ B cells in serial sections was performed under ethanol as previously described, ${ }^{14}$ to avoid lymphoid follicles or lymphoid aggregates in the inflamed mucosa. If the areas were large enough they were microdissected by hand under the microscope by scraping the dry section with a 25 gauge needle and subsequently washing the needle into $50 \%$ ethanol. The samples were dried and the DNA was released for PCR using proteinase $\mathrm{K}$ as previously described. ${ }^{14}$

PCR

$\mathrm{V}_{\mathrm{H}} 4.21, \mathrm{~V}_{\mathrm{H}} 6$, and $\mathrm{V}_{\mathrm{H}} 5$ family $\left(\mathrm{V}_{\mathrm{H}} 251\right.$ and $\left.\mathrm{V}_{\mathrm{H}} 32\right)$ genes were amplified from $10 \mu \mathrm{l}$ of the DNA preparation using our previously established methods. ${ }^{14}{ }^{15}$ Briefly, a nested reaction with the first round using family specific $V_{H}$ leader region primers and a $\mathrm{J}_{\mathrm{H}}$ primer, followed by a second round using family specific $\mathrm{V}_{\mathrm{H}} \mathrm{Fw}_{\mathrm{W}} 1$ region primers and a nested $\mathrm{J}_{\mathrm{H}}$ primer was performed, resulting in an amplified product of about 350 bp $\mathrm{V}_{\mathrm{H}}-\mathrm{D}_{\mathrm{H}}-\mathrm{J}_{\mathrm{H}}$ rearrangement. These products were visualised by running on a $3.5 \%$ agarose gel and staining with ethidium bromide.

CLONING AND SEQUENCING

PCR products were purified using the Hybaid Recovery ${ }^{\mathrm{TM}}$ DNA purification kit (Hybaid Ltd, Teddington, Middx, UK) and cloned into either the pMOS Blue T-vector (Amersham, Little Chalfont, Buckinghamshire, UK) or the pGEM-T vector (Promega, Southampton, Hampshire, UK) using the manufacturer's recommended protocol. The insert size was checked by PCR using T7 and Universal forward or reverse primers (as applicable) and cycling conditions as previously described. ${ }^{13}$ Clones were sequenced in both directions on an ABI377 automatic sequencer with the dye terminator cycle sequencing kit.

Analysis of sequences was performed with GeneJockey II software. $\mathrm{D}_{\mathrm{H}}$ and $\mathrm{J}_{\mathrm{H}}$ regions were identified using the $\mathrm{V}$ Base sequencing directory (MRC Centre for Protein Engineering, Cambridge, UK). The number of mutations in $\mathrm{V}_{\mathrm{H}}$ regions was determined by comparison with published germline $\mathrm{V}_{\mathrm{H}}$ sequences. ${ }^{16}$ The PCR error rate for these methods has previously been determined to be less than $0.2 \%,{ }^{14}$ therefore no more than one mutation per $350 \mathrm{bp}$ length is likely to be due to PCR error.

STATISTICAL ANALYSIS

Comparison of numbers of mutations in the $\mathrm{IgV}_{\mathrm{H}}$ regions was made using the MannWhitney $U$ test because the data from the patients with ulcerative colitis were not normally distributed.

The proportions of $\mathrm{D}_{\mathrm{H}}$ and $\mathrm{J}_{\mathrm{H}}$ segments used by the different populations were compared by $\chi^{2}$ analysis.

\section{Results}

IMMUNOGLOBULIN GENES IN PLASMA CELLS FROM PATIENTS WITH ULCERATIVE COLITIS HAVE A BIASED J $\mathrm{J}_{\mathrm{H}}$ REPERTOIRE

Twenty three different immunoglobulin genes from LP plasma cells in five different patients with ulcerative colitis were sequenced, and the closest matched germline $\mathrm{J}_{\mathrm{H}}$ segments were identified. $\mathrm{J}_{\mathrm{H}}$ usage of 24 sequences in LP plasma cells from five patients with Crohn's disease, and 15 sequences from five children of a similar age who did not have IBD, was determined for comparison. In addition, $\mathrm{J}_{\mathrm{H}}$ usage in 127 previously sequenced immunoglobulin genes from normal gut LP plasma cells ${ }^{15}{ }^{17}$ was determined. Figure 1 shows that the proportion of immunoglobulin genes from LP plasma cells in ulcerative colitis which use $\mathrm{J}_{\mathrm{H}} 4$ is reduced, and the proportion using $\mathrm{J}_{\mathrm{H}} 6$ is increased, compared with the above controls. $\chi^{2}$ analysis showed that these were statistically significant $(p<0.03)$ changes from the proportions found in normal gut LP sequences.

IMMUNOGLOBULIN GENES IN NAIVE B CELLS FROM ULCERATIVE COLITIS ALSO HAVE A BIASED $\mathrm{J}_{\mathrm{H}}$ REPERTOIRE

Observation of a biased repertoire of immunoglobulin gene components could be caused by 


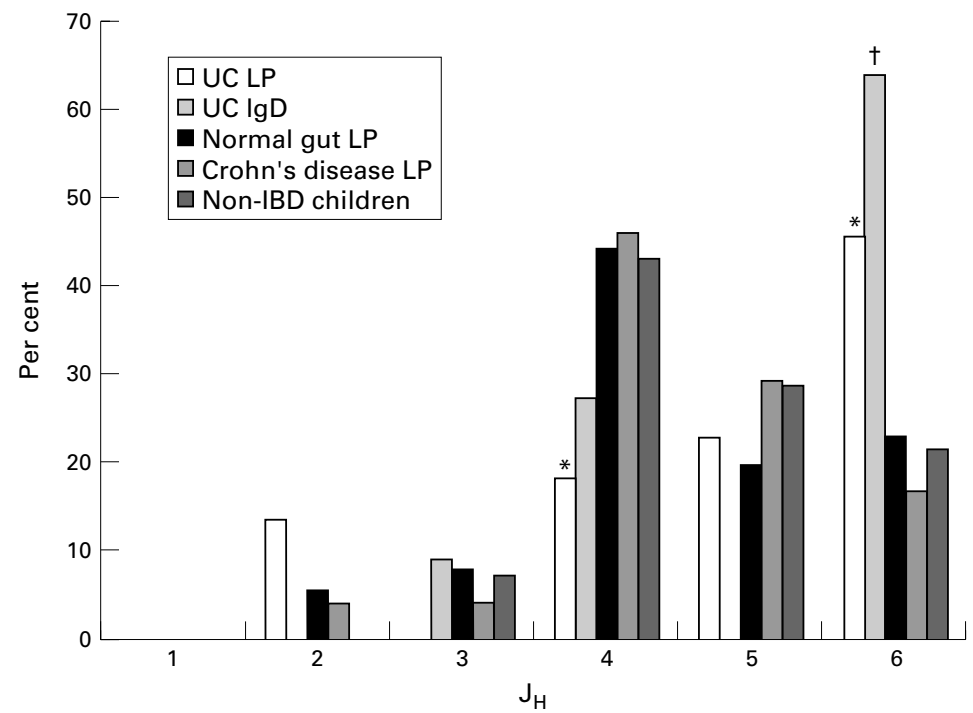

Figure $1 \mathfrak{f}_{H}$ usage in immunoglobulin genes. The percentages of each $\mathfrak{F}_{H}$ segment which were determined from 127 different immunoglobulin genes in normal lamina propria (LP) plasma cells $s^{13}{ }^{17}$ were used for statistical comparison. The percentages determined from immunoglobulin genes in ulcerative colitis (UC) are shown to the left of these, while the percentages determined from the control Crohn's disease group and those without inflammatory bowel disease (non-IBD children) are to the right. Significant differences are indicated: ${ }^{*} p<0.05 ; t p<0.005$.

antigen selection pressure or by an alteration in the factors affecting recombination. An effect of antigen selection would not be apparent until after the mutation and selection process in the germinal centre reaction. Therefore, to determine whether the above changes in immunoglobulin genes from children with ulcerative colitis were present in the naive $\mathrm{B}$ cell population, immunoglobulin genes from areas of $\mathrm{IgD}+$ virgin $\mathrm{B}$ cells were sequenced. $\mathrm{J}_{\mathrm{H}}$ repertoire in 12 germline sequences or sequences with only one mutation from germline (allowing for PCR error) was determined. A similar trend in $\mathrm{J}_{\mathrm{H}} 4$ usage (fig 1) was seen in this naive $\mathrm{B}$ cell population in ulcerative colitis, although it did not quite reach statistical significance when compared with the normal gut LP sequences. However, the increase in $\mathrm{J}_{\mathrm{H}} 6$ usage was significantly higher than normal $(\mathrm{p}<0.004)$.

$\mathrm{D}_{\mathrm{H}}$ USAGE

The germline $\mathrm{D}_{\mathrm{H}}$ gene segments used in the CDR3 regions were determined as far as possible on the basis of length and degree of homology. The minimum criterion for a match was taken to be $100 \%$ homology over a length of 5 bp, and fig 2 shows the proportions of each $\mathrm{D}_{\mathrm{H}}$ segment found. Previously reported frequencies of $\mathrm{D}_{\mathrm{H}}$ genes in normal PBLs, ${ }^{18}{ }^{19}$ acute lymphocytic leukaemia, ${ }^{20}$ and severe combined immunodeficiency (SCID) B cells ${ }^{21}$ have also been included for comparison. Where a value is marked with an asterisk, it was found to be statistically different from the proportion of that $\mathrm{D}_{\mathrm{H}}$ segment found in studies of PBLs at $\mathrm{p}<0.01$. There is a significant increase in the proportion of DXP'1 genes in LP plasma cells from patients with ulcerative colitis. This is similar to the previously reported increase in DXP'1 seen in B cells from SCID patients. ${ }^{21}$ No increase in DXP'1 was seen for patients with Crohn's disease, but there was a significant increase in the D4 gene segment, similar

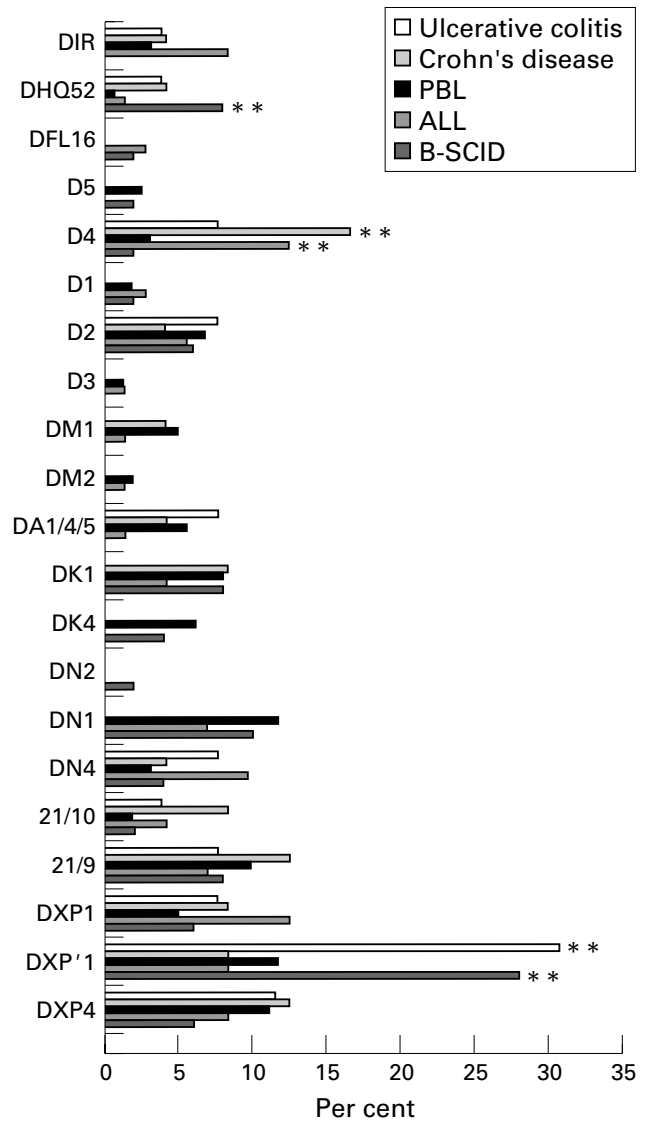

Figure $2 D_{H}$ usage in immunoglobulin genes. The percentages of each $D_{H}$ gene used in immunoglobulin genes from lamina propria plasma cells from patients with ulcerative colitis and Crohn's disease are shown compared with previously published data from patients with acute lymphocytic leukaemia (ALL), ${ }^{20}$ severe combined immunodeficiency (B-SCID), ${ }^{21}$ and normal peripheral blood leucocytes (PBL). ${ }^{18} 19$ Asterisks (**) indicate a significant difference from the percentage found in $P B L s$ $(p<0.01)$.

to that previously reported for patients with acute lymphocytic leukaemia. ${ }^{20}$

Because of the difficulty in comparing proportions where the sample size is less than the number of available groups, the non-IBD children and IgD+ ulcerative colitis groups were not included in this analysis. However, the trend in distribution of DXP genes in the IgD+ ulcerative colitis group was similar to that of the LP plasma cell ulcerative colitis groupthat is, there were two DXP'1 genes but no DXP1 or DXP4 genes. In the non-IBD children, three DXP genes were found, but none were DXP'1.

\section{HYPERMUTATION OF $\operatorname{Igv}_{\mathrm{H}}$ GENES}

The average number of mutations in the $23 \mathrm{IgV}_{\mathrm{H}}$ genes isolated from LP plasma cells in patients with ulcerative colitis was 11.0. This was significantly lower than that observed in the 22 genes from patients with Crohn's disease (average of $14.5, \mathrm{p}=0.023$ ), and was significantly lower than that found in the 15 genes from the control group of non-IBD children (average of 16.5, p = 0.021). There was no significant difference between the non-IBD group and the patients with Crohn's disease. There is a large range between the numbers of mutations in individual genes from each group as illustrated in fig 3 . One 
Figure 3 Number of mutations in immunoglobulin genes from patients with ulcerative colitis or Crohn's disease and non-IBD controls. Each individual point represents one immunoglobulin gene, and the average number is indicated by a diamond at the side of each group.

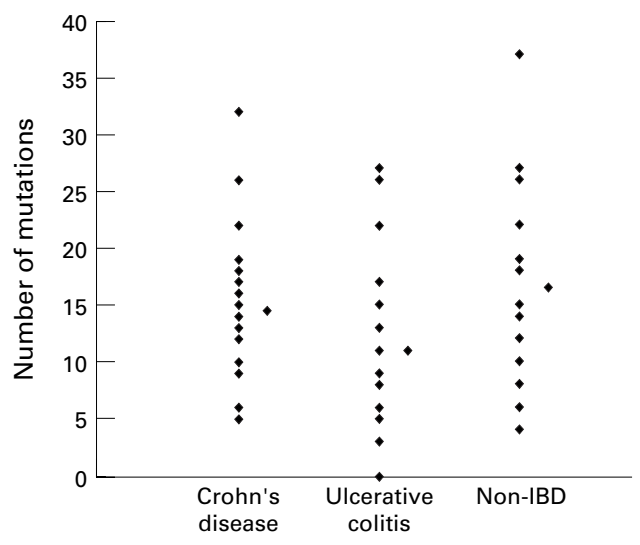

of the genes isolated from patients with ulcerative colitis was in germline configuration, but all other $\operatorname{IgV}_{\mathrm{H}}$ genes were mutated compared with the germline sequence.

\section{Discussion}

We have observed a bias towards the usage of $\mathrm{J}_{\mathrm{H}} 6$ and DXP'1 segments, and against the usage of $\mathrm{J}_{\mathrm{H}} 4$ segments, in patients with ulcerative colitis. Although it has been previously reported that $\mathrm{V}_{\mathrm{H}}$ usage in IBD is biased, ${ }^{22}$ this is the first report of a biased $\mathrm{J}_{\mathrm{H}}$ and $\mathrm{D}_{\mathrm{H}}$ repertoire in ulcerative colitis. These biases were not seen in the patients with Crohn's disease, or the non-IBD children, which had $\mathrm{J}_{\mathrm{H}}$ repertoires indistinguishable from those seen in immunoglobulin sequences from normal intestinal LP plasma cells and PBLs. ${ }^{17-19}$ There are large differences in the isotype of antibodies secreted by LP plasma cells in IBD and non-IBD patients, and a difference in IgG1 subclass between Crohn's disease and ulcerative colitis. ${ }^{1}$ However, these differences are unlikely to have caused the observed biases in $\mathrm{D}_{\mathrm{H}}$ and $\mathrm{J}_{\mathrm{H}}$ usage. $\operatorname{IgH}$ genes of the IgA and IgG isotypes in normal LP plasma cells showed the same trend in $\mathrm{J}_{\mathrm{H}}$ usage, when studied using reverse transcriptase PCR with 3' primers in the constant region (L Boursier, D Dunn-Walters, and J Spencer, unpublished observations). These primers cannot be used when working with DNA extracted from microdissected cells. The immunoglobulin gene segment repertoire can be skewed by the effects of antigen selection, where a particular gene segment encodes antibody with high affinity for the stimulating antigen and therefore predominates the response to that antigen. Alternatively, a change in immunoglobulin gene segment repertoire could result from fundamental differences in the genetics of immunoglobulin genes, either differences in the immunoglobulin segments available for recombination or differences in the actual recombination mechanism itself.

To determine whether our observations were due to antigen selection, or were a fundamental characteristic of $\mathrm{B}$ cells in ulcerative colitis, immunoglobulin genes from a population of putative naive pregerminal centre $\mathrm{B}$ cells $(\mathrm{IgD}+$ cells with unmutated immunoglobulin genes) were studied. The same statistically significant bias towards $\mathrm{J}_{\mathrm{H}} 6$ usage was observed and, although there were no statistically significant differences in $\mathrm{J}_{\mathrm{H}} 4$ and DXP'1 usage, the same trends could be observed with these segments. Confirmation of these observations in an unselected population of $\mathrm{B}$ cells indicates that they are likely to be caused by a fundamental difference in the genetics of immunoglobulin genes, rather than by the effects of antigen selection.

It is not known whether the alterations are of germline immunoglobulin gene composition or of fundamental differences in the method of immunoglobulin gene rearrangement. Comparison with other instances where the $\mathrm{J}_{\mathrm{H}}$ and $\mathrm{D}_{\mathrm{H}}$ repertoires are skewed showed some similarities but also showed many differences. Patients with B-SCID have a defect in the mechanism of immunoglobulin gene rearrangement, and the CDR3 regions in the few $\mathrm{B}$ cells that they have are significantly different from normal. The total length of CDR3 is smaller than controls, and there are fewer $\mathrm{N}$ nucleotides and more $\mathrm{P}$ nucleotides than normal. Analysis of $\mathrm{J}_{\mathrm{H}}$ segment usage shows an increase in the proportions of $\mathrm{J}_{\mathrm{H}} 1, \mathrm{~J}_{\mathrm{H}} 2$, and $\mathrm{J}_{\mathrm{H}} 3$. The most frequently used $\mathrm{D}_{\mathrm{H}}$ segment is DXP'1, and there is increased expression of the $\mathrm{D}_{\mathrm{H}} \mathrm{Q} 52$ gene segment. ${ }^{21}$ Some of these changes are similar to those seen in the foetal repertoire (short CDR3, increased $\mathrm{J}_{\mathrm{H}} 3$, increased $\mathrm{D}_{\mathrm{H}} \mathrm{Q} 52$ ), which is thought to be shaped, in part, by a fundamentally different rearrangement process in the foetus. ${ }^{23}$ The changes seen in ulcerative colitis have some similarities to those reported for SCID patients (decreased $\mathrm{J}_{\mathrm{H}} 4$ and increased DXP'1), which may indicate that there is a defect in recombination in ulcerative colitis. However, the CDR3 regions in ulcerative colitis do not have any other features common to the SCID or foetal repertoire. In fact, a preliminary analysis suggests that the length of CDR3 in the ulcerative colitis repertoire is greater than normal, even taking into account the increased usage of the larger $\mathrm{J}_{\mathrm{H}}$ segment, $\mathrm{J}_{\mathrm{H}} 6$ (data not shown).

Individual immunoglobulin gene segments will encode protein with a distinct conformation which may contribute towards the binding of particular antigens. Autoreactivity may therefore be associated with individual gene segments, such as the binding of antibodies encoded by $\mathrm{V}_{\mathrm{H}} 4.21$ to the red blood cell antigens $\mathrm{I}$ and $\mathrm{i}^{24}{ }^{25}$ or the preference for DXP'1 usage, which has been reported in antiDNA antibodies. ${ }^{26}$ In this context it is interesting that the autoantibody associated DXP'1 segment is overexpressed in ulcerative colitis. We have found no reports of $\mathrm{J}_{\mathrm{H}} 6$ overexpression being correlated with any particular antigenic specificity, but, in the light of the prevalence of perinuclear anti-neutrophil cytoplasmic antibodies and other disease specific autoantibodies in ulcerative colitis, ${ }^{2-6}$ this is an area that requires further investigation.

Differences in the content/regulation of immunoglobulin genes in ulcerative colitis would concur with the observations that indicate that it is, at least in part, an hereditary disease. Linkage analysis has implicated loci for ulcerative colitis on chromosomes 7 and $12 .{ }^{12}$ There have also been reports that HLA class II genes are associated with ulcerative colitis. ${ }^{27}{ }^{28}$ These reports do not appear to suggest that immunoglobulin genes themselves may be a factor. The IgH locus 
is on chromosome 14 and the genes TdT and RAGs $1 / 2$, which are known to be involved in recombination, are on chromosomes 10 and 11 respectively. However, there may be genes that affect immunoglobulin gene rearrangement which have not yet been identified, and which may be involved in the generation of biased $\mathrm{J}_{\mathrm{H}}$ usage in ulcerative colitis. Clearly, in the light of the information presented here, further investigation into the immunoglobulin segment repertoire is necessary in this disease. Future investigations will follow up this work on a wider range of patients of different age groups and patients with different disease activity. An hereditary origin of the biases observed here will be investigated by looking at $\mathrm{D}_{\mathrm{H}}$ and $\mathrm{J}_{\mathrm{H}}$ usage in the peripheral blood of patients with IBD and their relatives.

The data also showed that there was a slight decrease in the mean number of mutations per immunoglobulin gene in patients with ulcerative colitis (fig 3). This difference was significant when compared with both the Crohn's disease and the non-IBD controls. It is difficult to know how much emphasis to place on this observation, as the range in the number of mutations is extremely high in all cases. In any case, a decrease in the number of mutations per immunoglobulin gene indicates that there is no overstimulation to re-enter the germinal centre, such as would be caused by over reaction to $\mathrm{T}$ dependent antigens. Decreased mutation has previously been associated with immunoglobulin genes that recognise autoantibodies in their germline configuration. ${ }^{24}$ In this context it is also interesting to note that, in this small sample, a germline immunoglobulin gene was isolated from the LP of a patient with ulcerative colitis. Out of over 200 previously sequenced immunoglobulin genes from LP plasma cells, only one was germline..$^{13}$ It will be interesting to determine the percentage of germline genes isolated from patients with ulcerative colitis in future studies.

In conclusion, we have shown for the first time that there is a bias in immunoglobulin $\mathrm{J}_{\mathrm{H}}$ and $\mathrm{D}_{\mathrm{H}}$ segment usage in LP plasma cells of patients with ulcerative colitis, and this bias is not seen in controls. The same bias is evident in virgin B cells from patients with ulcerative colitis, which implies that it was not caused by antigen selection pressure. Further investigation needs to be carried out to determine the genetic basis of the bias and the relation, if any, of these observations to the prevalence of autoantibodies in ulcerative colitis.

This work was funded by the Special Trustees of St Thomas' Hospital (D D W) and the Crohn's in Childhood Research Association. We are grateful to Professor Tom MacDonald, Paediatric Gastroenterology, St Bartholemews Hospital, for allowing access to tissue specimens.

1 Brandtzaeg P, Halstensen TS, Helgeland L, et al. The mucosal immune system in inflammatory bowel disease. In: MacDonald TT, ed. Immunology of gastrointestinal disease. Dordrecht, Boston, London: Kluwer Academic Publishers, 1992:19-41.

2 Yang H, Rotter JI, Toyoda H, et al. Ulcerative colitis: a genetically heterogeneous disorder defined by genetic
(HLA Class II) and subclinical (anti-neutrophil cytoplasmic antibodies) markers. 7 Clin Invest 1993;92:1080-4.

3 Seibold F, Slametschka D, Gregor M, et al. Neutrophil antibodies: a genetic marker in primary sclerosing cholangitis and ulcerative colitis. Gastroenterology 1994;107:532-6.

4 Biancone L, Mandal A, Yang H, et al. Production of IgG1 antibodies to cytoskeletal protein by lamina propria plasma cells in ulcerative colitis. Gastroenterology 1995;109:3-12.

5 Halstensen TS, Das KM, Brandtzaeg P. Epithelial deposits of IgG1 and activated complement colocalise with the $M(r)$ $40 \mathrm{kD}$ putative autoantigen in ulcerative colitis. Gut 1993;34:650-7

6 Shorter DG, McGill DB, Bahn RC. Cytotoxicity of mononuclear cells for autologous colonic epithelial cells in colonic diseases. Gastroenterology 1984;86:13-22.

7 Leichtner AM, Jackson WD, Grand R. Ulcerative colitis. In: Pediatric gastrointestinal disease. Walker WA, Durie PR, Hamilton JR, et al, eds. New York: Mosby, 1991;1:712-26.

8 Lashner BA, Evans AA, Kirsner JB. Prevalence and incidence of inflammatory bowel disease in family members. Gastroenterology 1986;91:1396-400.

9 Helgeland L, Tysk C, Jarnerot G, et al. IgG subclass distribution in serum and rectal mucosa of monozygotic twins with or without inflammatory bowel disease. Gut 1992;33: 1358-64.

10 Terry SI, Rajendran A, Hanchard B, et al. Ulcerative colitis in sickle cell disease. $\mathcal{F}$ Clin Gastroenterol 1987;9:55-7.

11 Price WH. A high incidence of chronic inflammatory bowel disease in patients with Turner's syndrome. 7 Med Genet 1979;16:263-6.

12 Satsangi J, Parkes M, Louis E, et al. Two stage genome-wide search in inflammatory bowel disease provides evidence for susceptibility loci on chromosomes 3, 7 and 12. Nat Genet 1996;14:199-202.

13 Dunn-Walters DK, Isaacson PG, Spencer J. Sequence analysis of human $\operatorname{IgV}_{\mathrm{H}}$ genes indicates that ileal lamina propria plasma cells are derived from Peyer's patches. Eur $\mathcal{F}$ Immunol 1997;27:463-7.

14 Dunn-Walters DK, Howe CJ, Isaacson PG, et al. Location and sequence of rearranged immunoglobulin genes in human thymus. Eur f Immunol 1995;25:513-19.

15 Dunn-Walters DK, Isaacson PG, Spencer J. Analysis of mutations in immunoglobulin heavy chain variable region genes of microdissected marginal zone $B$ cells suggests that the MGZ of human spleen is a reservoir of memory B cells. f Exp Med 1995;182:559-66.

16 Tomlinson IM, Walter G, Marks JD, et al. The repertoire of human germline $\mathrm{V}_{\mathrm{H}}$ sequences reveals about fifty groups of $\mathrm{V}_{\mathrm{H}}$ segments with different hypervariable loops. F Mol Biol 1992;227:776-98.

17 Dunn-Walters DK, Boursier L, Spencer J. Hypermutation, diversity and dissemination of human intestinal lamina propria plasma cells. Eur F Immunol 1997;27:2959-64.

18 Yamada M, Wasserman R, Reichard BA, et al. Preferential utilisation of specific immunoglobulin heavy chain diversity atilisation of specific immunoglobulin heavy chain diversity phocytes. F Exp Med 1991;173:395-407.

19 Brezinschek HP, Brezinschek RI, Lipsky PE. Analysis of the heavy chain repertoire of human peripheral B cells using single cell polymerase chain reaction. F Immunol 1995;155: 190-202.

20 Steenbergen EJ, Verhagen, OJHM, van Leeuwen EF, et al. B precursor acute lymphoblastic leukaemia third complementarity-determining regions predominantly represent an unbiased recombination repertoire: leukaemic transformation frequently occurs in foetal life. Eur f Immunol 1994;24:900-8.

21 Minegishi Y, Akagi K, Nishikawa K, et al. Analysis of the $\mathrm{CDR} 3$ region of the rearranged $\mathrm{IgH}$ chain genes in patients with severe combined immunodeficiency and severe lymphopenia. F Immunol 1996;156:4666-71.

22 McCabe R, Carroll WL, Egan M, et al. Immunoglobulin variable region usage in human intestinal B lymphocytes. Clin Immunol Immunopathol 1994;71:240-5.

23 Schroeder HW, Perlmutter RM. Development of the human antibody repertoire. In: Gupta S, Griscelli C, eds. New concepts in immunodeficiency diseases. New York: John Wiley \& Sons, 1993:3-25.

24 Pascual V, Victor $\mathrm{K}$, Spellerberg $\mathrm{M}$, et al. $\mathrm{V}_{\mathrm{H}}$ restriction among human cold agglutinins. The $\mathrm{V}_{\mathrm{H}} 4-21$ segment is required to encode anti-I and anti-i specificities. F Immunol 1992;149:2337-44.

$25 \mathrm{Li}$ Y, Spellerberg MB, Stevenson FK, et al. The I binding specificity of human VH4-34 (VH4.21) encoded antibodes is determined by both $\mathrm{VH}$ framework region 1 and CDR3. F Mol Biol 1996;256:577-89.

26 Stewart AK, Huang C, Long AA, et al. VH gene representation in autoantibodies reflects the normal human B cell repertoire. Immunol Rev 1992;128:101-22.

27 Satsangi J, Welsh KI, Bunce M, et al. Contribution of genes of the major histocompatibility complex to susceptibility and disease phenotype in inflammatory bowel disease. Lancet 1996;347:1212-17.

28 Roussomoustakaki M, Satsangi J, Welsh K, et al. Genetic markers may predict disease behaviour in patients with ulcerative colitis. Gastroenterology 1997;112:1845-53. 